\title{
DIFFERENT EXEGESIS OF THE CONCEPTS RELATED TO MIXED TRANSPORT
}

This article contains a short history of existing types of mixed transport in Russia and abroad. The system of export freight delivery is analyzed in association with all forms of interaction between various modes of transportation and the subjects of the transport service market (TSM). There is focus not only on the transport complex organization departments and management levels of various modes of transportation, but also on other TSM subjects (carriers, cargo owners, forwarders, stevedores, marine agents, banks, organizations responsible for expertise, customs control and document completion, etc.).

Keywords: Mixed transport, multimodal transport, railway, trailer transportation system, piggybacking, containers.

\section{Introduction}

There are various approaches to interpreting the transport terms. According to UNCTAD (United Nation Conference on Trade and Development) intermodal transport refers to carrying goods by several modes of transport when one carrier is responsible for the whole delivery from one departure point through one or more transshipment points to the destination point. Depending on responsibility for transporting goods various shipping documents are issued. The person organizing multimodal transport is responsible for transporting the goods along the whole route, irrespective of the number of carriers when completing the single shipping document [1].

At the European Conference of Ministers of Transport held in 1994 it was stated that multimodal transport refers to transporting one type of freight by not less than two modes of transport, whereas intermodal transport means transporting goods by one mode of transport with the transshipment of the sealed container en route [2].

\section{Interpretations}

A. Avetikyan and N. Solovyeva [3] say that "integration between transporting and manufacturing processes gradually shifts from intermodality of cargo movement, i.e. internal isolation and autonomy from the results of producing goods, to transmodality (integration of freight transport by various modes of transport according to the single documents)".

According to V. Goryainov [4], L. Mirotina and Y. Tashbaev [5], intermodality is integrated 'from door to door' freight transport according to the single consignment; the transport involves at least two modes of transport.

The similar definition is given by V. Galaburda [6]: "Under the intermodal system the cargo is carried 'from door to door' by two or more modes of transport under single management and according to a single document (such system is also called 'direct mixed transport', though we don't think this is an apt term to describe the process).

The idea of intermodal transport is to deliver ULD (a container or package) according to the schedule agreed by all modes of transport under control of the forwarder that takes responsibility for meeting transportation conditions and completing the required documents. The forwarder (transport organization, container association, special forwarding company, etc.) as a legal entity concludes a contract with the cargo owner and transport organization (carrier) and takes responsibility to calculate the optimal transportation process and to ensure its quality... The system with the forwarder being one of the modes of transport and interacting modes being its customers is called the multimodal transport system".

The decision taken by the EU Ministers of Transport in January 1997 says: "Transport intermodality is the possibility to influence the dominance of one mode of transport over others...

\footnotetext{
* Petr Kurenkov, Alexey Astafiev, Olga Kaplina

Department of Transport business, Faculty Institute of Management and Information Technologies (IUIT), Moscow State University of Railway Engineering (MIIT), Russian Federation

E-mail: petrkurenkov@mail.ru
} 
Transport intermodality is aimed at integrated use of every mode of transport to benefit from its specific characteristics..."

O. Goncharuk [7] as well as L. Mirotin and Y. Tashbaev [5] say that "in contrast to intermodal systems where ULD are carried according to the single tariffs and shipping documents with all carriers having equal rights, in multimodal transport one mode of transport is the carrier whereas interacting modes of transport are the customers paying for the services".

S. Miloslavskaya [8] says: "Intermodal transport is successive transportation of cargo by several modes of transport in the same freight unit or vehicle without its reloading in transshipment. According to [8] "intermodal transport means carrying cargo in the same freight unit and the same vehicle which are successively used by the modes of transport without cargo handling when changing the mode of transport".

In the proceedings of the Conference on Transport and Environment (1996) we read: "Combined transport is intermodal transport with the largest part of the European route handled by railway, inland water or sea transport; any initial and/or final route section operated by road transport is maximally short".

According to N. Venzik [1] "combined transport in contrast to intermodal transport is transporting cargo in the same piece of freight or vehicle by combining road, railway and inland water transport”. L. Matyshina and L. Izosimova [9] write that 'according to the European Agreement on Important International Combined Transport Lines and Related Installations (AGTC) combined transport means transporting cargo in the same piece of freight, the same transport installations (large capacity containers, swap bodies, semitrailers and trucks) using several modes of transport".

In the materials prepared for the board meeting of the Russian Transport Ministry [10] we read: "Combined transport means carrying cargo using more than one modes of transport and organizing door to door transportation according to the single document". The definitions mentioned above are published in the digest prepared by the United Nation and Economic Commission for Europe - UN/ECE, European Conference of Ministers of Transport - ECMT and European Commission (Terminology on Combined Transport) route [2], where all these definitions are reduced to the same denominator.

As for the terms like amodal, bimodal, unimodal, threemodal, segmented and other transport, there is no confusion about their interpreting because they are used not often.

Amodal transport is control of moving transport and freight units irrespective of the modes of transport involved and the role each one plays in the transportation process (successive, parallel or combined). Amodal transport is controlled from one dispatcher center [3].

Bimodal transport is carrying cargo in specialized vehicles having chassis and wheelsets capable of moving both on highways as tractor trailers and on rails as wagons of freight trains and even as passenger cars.
The trailer transportation system is a system of freight delivery in ULDs - trailers (automobile trailers or semitrailers with canopy or special demountable bodies). Main goods transported are trucks, self-propelled machinery, bulky and heavy freight.

Bulky and heavy freight (pipes, steelwork) is placed on the vehicles (trailers, rolltrailers, heavy-load chassis) which avoids the need to dismantle the equipment into separate units for their transportation from the consigner to the consignee. Rolltrailers are used only for carrying freight in the sea and river links of this transport system. Other ULDs are used in continental transport involving motor and road and railway transport. Both vertical and horizontal (with various tractors) crane loading-unloading is used in depot processing.

Nowadays there are various approaches to interpreting the term 'piggybacking'. Can be transporting a truck, which initially was moving under its own power and later was placed onto the flat wagon, considered as piggybacking? Is the truck to be loaded? If so, transportation of neither the tsar's coach nor empty trucks on flat wagons can be referred to as piggybacking. Similarly, it would be incorrect to refer transportation of military machinery on flat wagons to piggybacking.

The unimodal transport means carrying freight by one mode of transport and one or more carriers. If one carrier is involved, it issues its own transport document: a bill of loading, consignment note, etc. If there are more carriers (e.g. the carrier that moves freight from one port to the other with the transshipment in an intermediate port), one of them can issue a through $B / L$ covering the whole journey. On the return side of the $\mathrm{B} / \mathrm{L}$ certain terms of transportation may be specified, and the carrier is responsible for the whole trip or only for the part of the trip covered by its own vessel [8].

The segmented transport means that the carrier organizing transportation may take responsibility only for its own part of the process. In this case it issues the $\mathrm{B} / \mathrm{L}$ to carry intermodal or combined transport [8].

Containerization has been successfully used since 1950s. According to "International Transport Journal" (Switzerland), in 1995 the share of containerized cargo was 95 percent - one third was transported 'port-to-port' whereas the rest was carried out by mixed traffic. In 1995 the world container fleet was over 50 million units.

The main container fleet (over 80 percent) includes generalpurpose large capacity ISO containers. Generally, mixed transport is carried out by 20 - and 40 -feet general-purpose containers. The International Convention for Safe Containers (CSC), 1972, has two goals: to maintain a high level of safety in the transport and handling of containers by providing generally acceptable test procedures and strength requirements, and to facilitate the international transport of containers by providing uniform international safety regulations.

The Convention applies to the great majority of freight containers used internationally, except those designed specifically 
for carriage by air. In the Russian Federation containers have the certificates issued by of the CIS Register or other standard certificates/documents. Special customs rules are drawn that regulate export and import of containers as well as container traffic record.

In the 1970s, shipping companies started unloading containers on the western coast of the USA; from there they were brought across the whole country to railway flat wagons with the final delivery by the road transport. American President Lines Ltd., a transportation and shipping company, that operated only in the Pacific region bought its own railway flat wagons and organized traffic of separate container trains. Initially, these trains went only to the East coast ports of the USA; from there containers were carried by road transport to eastern markets.

Later, amendments in the legislation enabled shipping companies to carry goods to the inland destination points, and these companies started transporting containers by rail from the western coast to every part of the country. Actually, this type of service known as 'landbridge' took the place of the marine container route across the Panama Canal to the East coast of the USA and to the Mexican Gulf.

This traffic can be divided into 'minibridge', 'microbridge' and 'landbridge'. Their common feature is that they are carried out according to the single tariff, to the single $\mathrm{B} / \mathrm{L}$ or other document; profit distribution between marine carriers responsible for doorto-door delivery and land carriers as their customers is agreed upon in the tariff.

The "minibridge" transport includes carrying freight/ container according to the single marine $\mathrm{B} / \mathrm{L}$ from the port of one country to the port of another country, then by rail (landbridge) to the second port of this country and from there to the railway inland terminal of the destination country.

Its basis is the through container rate calculated from the port of the departure country to the end terminal in the destination country. The "minibridge" tariffs are issued by marine carriers, not by railways that receive commissions for transporting freight (containers) on the land section of the route. A classic example of the "minibridge" land section is the route carrying freight between the East and West coasts of the USA.

Compared with the marine transport the "minibridge" system has a number of advantages' both the total time and transportation costs are reduced. Since 1983 double-deck trains have been operating between the USA coasts for container transportation, which resulted in 20-25 percent cost saving.

Container transport on the Russian Railways in international traffic is regulated by the following documents:

- the instruction on how to record freight trains, wagons and containers passing through the division points;

- rules of operating, tracking each number of the container fleet and making calculations for using general-purpose containers of other countries' ownership;

- and other regulating documents.
Container systems prove to be highly efficient on the routes with stable flows of general cargo.

The essence of the palletized transport is to enlarge the piece of freight mainly with flexible bundling and flat pallets.

The cargo is placed on them forming packets with the parameters adequate to use freight capacity and carrying capacity of vehicles, transshipment equipment as well as to ensure safe transportation of cargo, to provide complex mechanization of loading-unloading operations, and to reduce the time required for handling the vehicles.

The terms of commerce have various interpretations. Thus, for example, the $\mathrm{B} / \mathrm{L}$ tells about the cargo whereas the Customs code about the goods. One and the same cargo can be declared under different codes which may cause incorrect charging of the customs duty.

From what has been said above we can draw a conclusion that the definitions of the types of the mixed transport are to be formulated depending on what party is responsible for transportation, what procedure is followed when completing the shipment documents, the role of each mode of transport, the number of national boundaries to be crossed and geography of these countries and other factors.

However it should be admitted that the terminology concerning freight traffic involving various modes of transport is far from perfect.

It is easier to use the common definitions of various modes of transport: local, direct, mixed direct, direct international, direct mixed international, etc. However, to play an equal role on the international transport market and be adapted to globalization processes we are to know generally accepted terminology which is not as simple as one may think [11], [12] and [13].

There is not much experience in the organization of piggyback traffic which causes a number of problems in the interaction of various agencies dealing with the customs clearance of cargo and vehicles used for its transportation (tractor and trailer rigs and railway flat wagons).

For this reason of primary importance is to analyze normative documents regulating this traffic both in the home country and abroad (international agreements, federal laws, other normative and regulatory legal acts) to pick up the rules and regulations that are to be captured in legislations or (if necessary) amended. As the concepts of "contrailer" and "piggyback traffic (shipment)" are ambiguous, a number of amendments should be introduced into some federal laws (for example, the federal bill "On mixed (combined) transport") and other regulatory legal documents.

Under present economic conditions logistic management of the export freight delivery in the mixed transport is to provide optimal work of transport agencies; it is aimed at improving operating and regulating activity by using reserves of the transportations system and optimizing interaction and coordination of all TSM players involved in export freight delivery. 
Managerial decisions are to provide coordinated solution of global and local tasks to achieve the common goal - increasing freight transport profitability and satisfying the cargo owner' needs (the cargo is to be delivered in time, in the required volume and according to high-quality standards). In other words, the managerial decision is to be taken on logistics principles.

According to the estimates of the $1970-80$ s, over 90 percent of freight transported by sea transport and about 50 percent of cargoes carried by river transport are transferred to railways or come from the railway transport. Therefore, the main problem of organizing the work not only of transport hubs based in sea ports but of those based in river ports was improving of all forms of interaction and coordination between railway and river transport, such as organizational, informational, technological, technical, commercial, economic, financial, legal forms, etc.

Usually a transport hub is the place of interaction between railway and road transport; road and water transport; railway and water transport, railway, road and water transport. Besides, these modes of transport interact with the industrial transport.

Interaction between railway and water transport is carried out in a greater number of transfer points (compared with sea transport), but the volume of work in river ports is not as large as in sea ports. Compared with sea ports, river ports more actively interact with road transport.

During the pre-reform period, transport hubs used to solve their tasks through close interaction and cooperation between related enterprises - railway stations, sea and river ports being the part of the transport hub, as well as truck agencies.

Some authors interpret coordination and interaction as synonyms. We do not agree with this point of view. There is no single approach to picking out the forms, areas, methods, spheres, aspects etc. of coordination and interaction and describing the role every concept play in the whole process.

Some authors say that coordination is harmonization of fundamental directions, complex planning of the development of various transport modes, improving management and control systems, cooperating in legal regulation of all modes of transport in the Unified transport system. Coordination mainly refers to the highest levels of transport hierarchy (ministries) and, partially, to the middle levels (railway administrations, shipping companies, regional department of road transport).

Interaction is aimed at coordinated decision making to complete fundamental directions of coordination between various transport modes; of primary importance is to complete the plans of transporting goods with the least expenses. Its goal is to optimize operational planning and monitoring of the coordinated work of every transport agency. It should be stressed that the interaction between the services within every mode of transport as well as other enterprises of the national economy is required.

Other authors say: "Interaction between modes of transport means coordination of operations in various transport modes involved in the whole transportation process. Coordination is coordination of the activities of the transport bodies and links to achieve maximum efficiency in carrying goods. With the increased traffic volume and modernized machinery and technology of all modes of transport their coordination is of special importance. Breaking freight delivery times and malicious use of vehicles is mainly caused by the lack in coordination between the links of the transportation chain. For this reason, better coordination in the transport industry is at the top of the agenda.

During the pre-reform period interaction was carried out at the middle links of the transport hierarchy (railway administrations and shipping companies) and, mainly, at its lower links (railway divisions, stations, ports, wharfs, truck agencies, etc.). Interaction between all modes of transport (in large hubs) was referred to as complex; in case two or three transport modes were involved interaction was bi-three-lateral.

Nowadays when export freight passes through sea and river ports interaction is carried out not only between various modes of transport but also between carriers and forwarders, between forwarders and cargo owners, between forwarders and stevedores, between stevedores and agents, between agents and the customs, between forwarders and the customs, etc. In other words, nowadays interaction and coordination cover practically all levels of management of all transport modes. As the export freight mixed transport involves not only government bodies but also private companies, the transport market is an intricate system: government and commercial structures both interact and coordinate at every level of management.

The system of freight goods delivery moves transport and freight flows as well as information, financial and energetic flows; hence various forms of coordination and interaction between various modes of transport and the TSM subjects.

Some authors say that "there are several forms of interaction between various transport modes: economic technical, technological, organizational, commercial and legal”.

Latest achievements in computer engineering encourage the development of the informational form of interaction.

V. Galaburda [6] says: "Interaction of transport modes is carried out in the technical, technological and economic forms. Coordination of transport modes is to be carried out in the organizational and legal areas. Coordination in the organizational area, to be more exact, in the area of the national transport management, is aimed at correcting mistakes caused by organizational disunity of separate transport modes and their subordination to various transport ministries, organizations and departments".

A. Komarov [14] points out: "The tasks of development coordination and interaction between various modes of transport are diverse and can be solved in the planned-economic, technical, technological, financial, organizational and legal spheres (areas). There is also an informational sphere (area) of interaction, but it is obviously a component part of technological interaction”. Some 
authors say about the areas of interaction, whereas others prefer spheres of coordination.

\section{Conclusions}

Under the market conditions, apart from interaction and coordination between various modes of transport and TSM subjects, special attention should be paid to the competition factor.

Competition on the TSM is seen not only between various modes of transport and between transport departments of various countries but also between transport companies dealing with forwarding, agency service, declaring, store handling, stevedoring etc. and having the right to render or resale services of one or several modes of transport.
Besides, competition is seen in every marine port, between Russian and foreign ports of one sea basin and one region.

RZD JSC and Transport Ministry agencies are to conduct regular advertising campaigns for ship owners and forwarders to attract export freight flows to the Russian transport communications and ports.

Integration and partnership of TSM subjects, EDM, latest computing technologies, flexible tariff and tax policy supported by the normative and legal basis, complex management of transport, freight, information, financial and energetic flows in the legal framework are certain to improve management efficiency at every stage of export freight traffic in the mixed transport.

To improve the quality of transport service the term "legal logistics" should be used meaning timely preparation and approval of normative legal acts regulating the interrelations in the legal framework, particularly, between the TSM subjects when carrying out export freight traffic in the mixed transport.

\section{References}

[1] VENZIK, N. G.: The Role of Mixed Transport in Foreign Trade, Marine Transport - Technology of Maritime Transport and Sea Ports, No. 11, 1996, pp. 1-20, Moscow: Mortekhinformreklama.

[2] Terminology on Combined Transport, New York : Geneva : Un. Nation and Economic Commission for Europe (UN/ECE), 2001.

[3] AVETIKYAN, A. A., SOLOVYEVA, N. P.: Marketing and its Role in Organizing the Transport Process, Railway Transport, No. 8, Moscow, 1992, pp. $72-77$.

[4] GORYAINOV, V. S.: Intermodal Transport - Maritime Transport and Intern. Navigation. Right and Economic Problems, XIV intern. conference World on Sea, Moscow, 1985, Moscow, 1990, pp. 539-542.

[5] MIROTIN, L. B., TASHBAEV, Y.E.: Intermodal and Multimodal Systems, Transport: Science, Engineering, Management, No. 3, Moscow, 1993, pp. 3-9.

[6] PERSiAnOV, V. A., TIMOSHIN, A. A., MILOSLAVSKAYA, S. V. et al.: Unified Transport System, Ed. by V. G. Galaburda : Moscow, 1996.

[7] GONCHARUK, O. V.: Economic Efficiency of Storage-and-retrieval Systems, Moscow : Nauka, 1991.

[8] MILOSLAVSKAYA, S. V.: Landbridges in the System of International Transport Communications, Transport Information Bulletin, No. 5, Moscow, 2000, pp. 32-35.

[9] MATYUSHIN, L. N., IZOSIMOVA, L. P.: Marketing Research of the Combined Transport of High Capacity Trucks and Semitrailers, VNIIZHT Bulletin, No. 5, Moscow, 1996, pp. 16-21.

[10] Materials for the meeting of the RF Transport Ministry Board: General Results of the Social and Economic Development of the Transport Complex in 1997 and the Tasks Set for 1998, Moscow, 1998.

[11] MARKUSHIN, V.: Globalization as God and Devil of the 21 st century, Moscow : Zavtra, No. 32, 2001.

[12] PERSIANOV, V. A.: Economic Globalization and Transport, Transport Information Bulletin, No. 2, Moscow, 2001, pp. 48-55.

[13] PERSIANOV, V. A., FEDOROV, L. S.: Transport in Russia and WTO, Railway Transport, No. 9, Moscow, 2001, pp. 24-29.

[14] KOMAROV, A.V.: Interaction between Railway and Water Transport in Mixed Traffic, Moscow : River Transport, 1957. 